\title{
THE IMPLEMENTATION OF TEACHING SPEAKING PROGRAM AT LANGUAGE CENTER ENGLISH COURSE PARE KEDIRI
}

\author{
Eko Nurohman
}

\begin{abstract}
Non - formal education is one of the solution to help the student learning the subject.One of non - formal education is English course to complete the studying in formal education, to give more knowledge, human skill, and to be able to develop the ability, improving the skill and independence. When the students cannot get maximal in speaking English at school, they can join some courses that is focusing on English. LANGUAGE CENTER English Course has known well to make students able to speak English because they will be helped by 100 teachers who is professional in English. The Implemntation of teaching speaking program at LANGUAGE CENTER English Course are including teacher's preparation, material taught, teachers' evaluation in learning, and students' response toward the teacher in teaching speaking. The research used descriptive qualitative as research design. The subject was 13 students of basic speaking class at LANGUAGE CENTER English Course. The method used in collecting data was interview, observation and documentation. Interview and observation were used for collecting data on teacher's preparation, material taught, teachers' evaluation in learning, and students' response toward the teacher in teaching speaking at LANGUAGE CENTER English Course and documentation used for collecting picture and video that we did research. The result of research is to show that teacher's preparation, material taught, teacher's evaluation and students' response in teaching speaking program at LANGUAGE CENTER English Course was very good.
\end{abstract}

Keyword: speaking, teaching

\section{BACKGROUND}

As one of the parts of the global community, we cannot deny that English is important for the educational development. English is taught from the elementary level to the university level. In the classroom activity, some of the students are able to speak fluently and mostly are at low level. At schools, students have to learn four skills of English, those are listening, speaking, reading, and writing. Speaking is needed to communicate because of mastering speaking skill. Students are able to make conversation with others, to give the ideas and to get the information. Most of students still cannot explain something well by using English.

Speaking is used to give instructions or to get things done, for example, to describe things or someone, to complain about people's behavior, asking and giving services and others. The English instruction in some schools does not 
demonstrate a satisfactory result. The teachers cannot deny the fact that this failure is caused by many problems during the instructional process. The problems of teaching are to be of particular importance. They have become interesting topics to discuss and analyze, especially for those who are directly involved with the teaching of English. However, the most important thing is teachers who are directly involved with the instructional activities. The teachers must try to look for the best solution to overcome the problems in order to reach the target of the teaching of English.

At school, the teachers give less attention to speak English. The teachers must have teaching strategies to make them practice their English-speaking skill. The teacher must be able to manage their assignments effectively. They are demanded to motivate the students in order to learn English well. By that statement, teaching method becomes the main point of the teaching learning English.

Based on some cases, Language Center (LC) English Course attempts to improve the speaking ability of the students. Language Center (LC) English Course is one of many courses in English village. To provide best learning system, LC focuses on three important things. The learning system are the qualified tutor and luxury infrastructure. The learners get some more facilities such as English camp, food, traveling and soon. The learners can focus in their learning by full day class. The program of LC are Intensive Program Package, Travelling Package, Full service Package, Holiday Package, TOEFL and IELTS, English Master, ILC (International Language Class)

The study findings are expected to provide valuable contribution to the program in improving English speaking ability. The study will be conducted by the title "The Implementation Of Teaching Speaking Program At Language Center English Course In Pare Kediri”.

\section{METHODS}

The design used in this study was a descriptive qualitative. It is designed to obtain information relating to the current status of phenomenon and presented toward determining the nature of situation that happen at a time of the research activities, not giving any treatment then describing the teaching speaking process happened at Language Center English Course. The researcher directly observed the process of teaching speaking that happened there. The researcher only collected the data and analyzed data to find the conclusion of research, and made an interpretation about the phenomenon which happened during the observational process descriptively. The researcher here described teacher's preparation, material taught, teachers' evaluation in learning, and students' respond toward the teacher in teaching speaking at Language Center English Course.

It was established in Pare, August $08^{\text {th }} 2015$ by Mr Abdul Wasik, Mr Arif Kuswanto and Mr Frandi in Singgahan, Pare, Kediri. This course is located on J1. Langkat No.88 Singgahan-Pare Kediri. LC is qualified Institution and worthy enough to improvie English language which provide better learning.

The method used in collecting data was interview, observation and documentation. In this research the instrument used to collect data was 
observation, interview and documentation. Interview and observation used for collecting data on teacher's preparation, material used, media used, method used, teachers' evaluation in learning, and students' respond toward the teacher in teaching speaking at Language Center English Course and documentation used for collecting picture that we did research.

\section{FINDINGS AND DISCUSSIONS}

The teacher's preparation was syllabus and lesson plan. The result of interview and observation were presented bellow. it was answered by the coordinator of basic speaking program in first month at Language Center English Course and the teacher of speaking at Language Center English Course. Based on the the interniew and document could be found that Language Center English course had syllabus. The syllabus was very simple consisting of the material taught in LC. The lesson plan is the learning activity of the teacher in the classroom.lesson plan can guide the teacher to handle the class. The interview on 24th February 2018, It was answered by mr Abdussalam as the coordinator of basic speaking program in first month at Language Center English Course and the teacher of speaking at Language Center English Course. The most important finding in this research was to answer focus of study discuss about it.

It is in line with Parkes, J (2002) states that syllabus is a contract, permanent record, and learning tool. Thus, syllabus helps teachers control their class and manage their efficient time

To know the material used in speaking class, we used interview and observation. The material of speaking applied in 16 meetings .The material taught supported the students to be confident to speak English. Teaching speaking material in LC was about introduction, telling time and daily activity,family ,describing picture and so on. It is suitable with the goal of teaching speaking that teaching speaking should be taught in attractive and communicative activities. There are many types of classroom speaking activities. Harmer (2001:348-352) states there are six classroom speaking activities.

it is known that the evaluation of the teacher was taken by the score from their performance, It is appropriate with Arikunto (2009) in his book entitled "Dasar-Dasar Penilaian Pendidikan", evaluation techniques that can be used as the assessment of the educational unit are written tests, observation, performance tests, portfolio assessment, self-assessment, and peer assessment.

The teacher always supports and gives them motivation as the teacher's role. It is in line with Breen and Cadlin in Nunan, (199:87). They state that the teacher has three main roles in communicative classroom to act as facilitator of communicative process as a participant as an observer and learner. that teachers had role to create teaching-learning situation. As the result, the students can receive the lesson easily.

\section{CONCLUSION}

The conclusion of this research is based on the focuses of the research, it can be concluded that there are some points related to the teaching speaking program at Language Center English Course. The researcher described the 
teaching speaking into some parts They are: (1) the teacher's preparation of teaching speaking program at Language Center English Course, (2) The material taught in teaching speaking program at Language Center English Course, (3) the teacher's evaluation of teaching speaking program at Language Center English Course, and (4) the students' response toward teaching speaking program at Language Center English Course

The teachers' preparation did by the teacher of Language Center English Course was very good because she had syllabus and lesson plan in every teaching. The teachers motivated the students to be brave to speak English.It was stupported by English zone and role. The material taught in teaching speaking class was variant to make the students to be antusiastic. The teacher was creative to take many suitable materials such as story that can make the students active their speaking as the goal of teaching speaking that teaching speaking should be taught in attractive and communicative activities and all stories had moral value that can be taken by students.

The evaluation did by the teacher was very good because it was done in every performance by giving the score according to scoring rubric of speaking and it was averaged in every Friday to know the students who got difficulties in learning and tried to look for the solving and it was evaluated again to get the final score. The students' response in speaking class was very good. The students were enjoying, enthusiastic and active in the activities during the class because the teacher was funny and she always supports and gives them motivation without giving homework.

\section{REFERENCE}

Alvey, R.G. 1974. The Historical Development of Organized Storytelling to Children in the United States. Phd Dissertation: University of Pennsylvania.

Arikunto, S. 2009. Dasar - dasarEvaluasiPendidikan (Edisi Revisi). Jakarta: BumiAksara.

Asher, J. (2000). Learning Another Language Through Actions. (6 ed). California: Sky Oaks Productions, Inc. Los Gatos.

Brown. 2001. Language Assesment: Principles and Classroom Practices. San Fransisco State University: Longman.

Brumfit, C. Q. Friends. 1997. Teaching English to Children. England: Longman Group Ltd.

Celce-Murcia, M. 2001.Testing English as a Second Language. New Delhi: Tata McGraw-Hill Publishing.

Chaney. 1998. Language Teaching a Scientific Approach. New York: Grow Hill Publishing Company.

Gilbert et all. 2011. Health Education: Creating Strategies for School and Community Health. United States of America: Jones and Bartlett Publisher. 
Harmer. 1991.Introduction to Research in Education. New York: Holt, Rinehart and Wiston.

Harris, Cook, V. 1993. Linguistics and Second Language Acquisition. US: Macmillan

Hopkin, David. 1993. A Teacher's Guide to Classroom Research. Buckingham: Open University Press.

Hornby. 1995. Principles of Language Learning and Teaching, (3 ed).

Ikawati, S. 2012. The Use of Newspaper in Teaching Speaking for SMU Students in SMU 97 Jakarta. Jakarta: The University of Jakarta. (Unpublished Script).

Kayi. 2006. Teaching Speaking: Activities to Promote Speaking in a second Language. Nevada:University of Nevada.

Klippel, Friederika, 1984. Keep talking Communicative Fluency Activities for Language Teaching. New York: Cambridge University Press.

Lado, R. 1961. Language Teaching a Scientific Approach. New Delhi: Grow Hill Publishing Company.

Mason, RD.,lind, DA, \&Marhal, WG, 1988. Statistic and introduction.florida: harcout branch javanovich,publisher.NewYork:RoudledgeFalmer.

Nunan, David. 2003. Practical English Language Teaching. New York: McGrawHill

Pederson, Paul. 1995. The Five Stages of Culture Shock: Critical Incident Around the World. United States of America: Greenwood.

Richards, C. 1977. Approaches and Methods in Language Teaching. Cambridge : Cambridge University press.

Schollaert, Rudi. 2003. Disclosing the Treasure Within: Towards School as Learning Communities. Netherlands: Garant Publisher.

Setijowati. 2013. Management Research Methodology: Integration of Principles, Methods and Techniques: Yogyakarta: Grahallmu.

Tarigan, Guntur Henry. 1987. Berbicara sebagai Suatu Keterampilan Berbahasa. Bandung: Penerbit Aksara.

Theodore Huebner. 2012. Speaking Across the Curriculum: Practical Ideas for Incorporating Listening and speaking into Classroom. New York: Idea Press.

Wagen \& Ridley. 1997. Your Guide to Training andAssesment in the National Qualifications Framework. Pretoria: Kagiso Publisher. 